\title{
HEAVY METALS AVAILABILITY AND SOIL FERTILITY AFTER LAND APPLICATION OF SEWAGE SLUDGE ON DYSTROFERRIC RED LATOSOL
}

\author{
Disponibilidade de metais pesados e fertilidade de um Latossolo Vermelho \\ distrófico após aplicação de lodo de esgoto
}

\author{
Rodrigo Santos Moreira ${ }^{1}$, Ronaldo Luiz Mincato², Breno Régis Santos²
}

\begin{abstract}
Sewage sludge is the solid residue obtained from urban sewage treatment plants. It is possible to use the sludge in a sustainable way as fertilizer and as soil conditioner due to its high levels of organic matter and nutrients. Besides pathogens and volatile organic compounds, the residue may also contain heavy metals which may accumulate and contaminate crops and the food chain. The aim of this study was evaluates the changes in the fertility of dystrophic Red Latosol and in the availability of heavy metals following application of sewage sludge. It was assessed whether organic matter supplied to the soil as large amounts of sewage sludge would decrease availability of heavy metals in the soil due to of insoluble compounds formation. From this, an experiment was carried out in polyethylene pots using lettuce plant for test. Sewage sludge were applied to the soil in concentrations equivalent to 60,120 and $180 \mathrm{t} \mathrm{ha}^{-1}$, and a control without sludge, in four replicates, in a completely randomized design. The results show that sewage sludge led to an increase of organic matter contents, of the cation exchange capacity (CEC) and of nutrients found in the soil. It also improved plant growth up to a concentration of $120 \mathrm{t} \mathrm{ha}^{-1}$. Availability of heavy metals, however, was reduced in sludge concentrations starting with $120 \mathrm{tha}^{-1}$.
\end{abstract}

Index terms: Biosolids, soil pollution, nutrients, Lactuca sativa.

\section{RESUMO}

Lodo de esgoto é o resíduo obtido após o tratamento dos esgotos municipais. Em decorrência dos elevados teores de matéria orgânica e de nutrientes, é possível utilizar o lodo, de forma sustentável, como fertilizante agrícola e condicionador de solos. Todavia, além de patógenos e de compostos orgânicos voláteis, esse resíduo pode conter ainda metais pesados que podem ser acumulados e contaminar as culturas agrícolas e a cadeia trófica. Assim, neste trabalho, objetivou-se avaliar as alterações na fertilidade de um Latossolo Vermelho distrófico e na disponibilidade de metais pesados decorrentes da aplicação de lodo de esgoto. Foi avaliado se a matéria orgânica fornecida ao solo com aplicações elevadas de lodo deverá, em razão da formação de compostos insolúveis, diminuir a disponibilidade dos metais pesados do solo. Para tanto, foi conduzido experimento em vasos de polietileno, com a aplicação do lodo no solo nas concentrações equivalentes a 60,120 e $180 \mathrm{t} \mathrm{ha}^{-1}$, e um tratamento controle sem lodo, com quatro repetições, em delineamento inteiramente casualizado, utilizando alface como planta teste. Os resultados indicam que o lodo de esgoto promoveu o aumento dos teores de matéria orgânica, da capacidade de troca catiônica (CTC) e de nutrientes no solo e ainda melhorou o desenvolvimento das plantas até a concentração de $120 \mathrm{t} \mathrm{ha}^{-1}$. A disponibilidade dos metais pesados, no entanto, foi reduzida nos tratamentos a partir de $120 \mathrm{t} \mathrm{ha}^{-1}$ de lodo.

Termos para indexação: Biossólidos, poluição do solo, nutrientes, Lactuca sativa.

(Received in september 3, 2013 and approved in october 1, 2013)

\section{INTRODUCTION}

Currently, the diversity of human activities and demographic growth contribute to increase residue production. Improper disposal of those residues results in environmental degradation of landfills (KORF et al., 2008).

Sewage sludge or biosolids is the residue obtained from domestic wastewater treatments, in a way that allows treated effluents to return to environment, causing no pollution (SINGH; AGRAWAL, 2008). If final disposal of those biosolids is not appropriate, it can become a new environmental problem.
Sewage sludge contains high levels of organic matter in addition to macro and micronutrients which are essential to plants, mainly $\mathrm{N}$ and $\mathrm{P}$, improving chemical, physical and biological properties of soils (CESAR et al., 2012). Therefore, its application as fertilizer and as soil conditioner is the best disposal alternative due to its low cost, reduction in use of chemical fertilizers, and avoidance of specific landfills for sewage sludge. However, sludge may have high levels of heavy metals which might accumulate in the soil and be absorbed by crops and, consequently, influence production negatively due to toxic effects. Heavy metals do not degrade by biochemical

\footnotetext{
1Universidade Federal de Alfenas/UNIFAL - Rua Gabriel Monteiro da Silva - 700 - Centro - 37130-000-Alfenas - MG - Brasil-rodrigosagro@yahoo.com.br ${ }^{2}$ Universidade Federal de Alfenas/UNIFAL - Alfenas - MG - Brasil
} 
processes due to resistance to microbial degradation and may be bioaccumulated and biomagnified along the food chain (LIAO et al., 2006).

Addition of organic matters to soil may reduce potential risk of heavy metals in the environment, by reducing its mobility and availability. This reduction may be influenced by several factors, among them: nature itself and degradability of organic matter, salts contents, effect of soil $\mathrm{pH}$, by the redox potential and by the type of soil (SHUMAN, 1999). Therefore, at the same time sewage sludge supplies metal to the soil, organic matter may act as an immobilizer of those metals, reducing their availability.

Thus, the aim of this study was evaluates the changes in the fertility of dystrophic Red Latosol and in the availability of heavy metals following application of sewage sludge. It was assessed whether organic matter supplied to the soil as large amounts of sewage sludge would decrease availability of heavy metals in the soil duo to of insoluble compounds formation.

\section{MATERIAL AND METHODS}

The experiment was carried out in Alfenas, Southern of Minas Gerais state, Brazil. The area is found at $21^{\circ} 25^{\prime}$ West of Greenwich, average altitude at $880 \mathrm{~m}$. According to Köppen, climate in the region is the tropical mesothermic or tropical of altitude type, annual average temperature at $21^{\circ}$ to $23{ }^{\circ} \mathrm{C}$, and $1,500 \mathrm{~mm}$ of rainfall. Clayey dystrophic Red Latosol, dominant in Alfenas, was used. Previous to the experiment, the soil was characterized and chemical characteristics are listed in table 1.

Sewage sludge used was produced at the Santana Sewage Treatment Plant in Varginha, also located in the Southern of Minas Gerais State. Six samples representing dehydration tanks were collected for physic and chemical analyses.

The samples were dried in oven at $65^{\circ} \mathrm{C}$ for three days. Next they were ground, quartered and stored in plastic recipients. Samples were, then, solubilized in aqua regia $\left(\mathrm{HNO}_{3}\right.$ and $\mathrm{HCl}$ at the rate 1:3) to have heavy metals analyzed, and $\mathrm{Cd}, \mathrm{Cr}, \mathrm{Cu}, \mathrm{Pb}, \mathrm{Mn}, \mathrm{Zn}, \mathrm{Ni}$ and $\mathrm{Fe}$ were quantified by Inductively Coupled Plasma Optical Emission Spectrometry (ICP-OES) (Model Optma 7300 DV, Perkin Elmer).

Total solids and inorganic solids were determined by mass loss at $105{ }^{\circ} \mathrm{C}$ and $500{ }^{\circ} \mathrm{C}$, respectively, and humidity and volatile solids were obtained by subtraction. Determination of $\mathrm{pH}$ was by peagameter (Model EA 940, Orion, USA) in suspension of soil and $\mathrm{CaCl}_{2}$ at a rate of 1:5. Determination of total $\mathrm{N}$ was by the Kjeldahl method. Total carbon and organic matter were obtained by the Walkley and Black method (ALLISON, 1973) and the P, K, Ca, Mg and S nutrients, according to Raij et al. (2001).

The experiment was carried out in a greenhouse, using $6 \mathrm{dm}^{3}$ polyethylene pots. A control treatment (without sludge), and treatments with concentrations of sewage sludge at 60,120 and $180 \mathrm{t} \mathrm{ha}^{-1}$ were studied. Independent of the nutrients, the doses were based on the heavy metal content of the sludge in order to provide large amounts of metals to the soil and to evaluate the effect of organic matter on its availability. Each treatment was repeated four times, at completely randomized design. Limestone was applied to all treatments at a concentration equivalent to a $1.2 \mathrm{t} \mathrm{ha}^{-1}$, calculated to increase the saturation of soil bases to $70 \%$. The different treatments underwent a 30 day incubation period. Finally, $0.5 \mathrm{dm}^{3}$ samples of soil were collected from each pot.

For the analyses, all soil samples from treatments were air dried, powdered and sieved with a $4 \mathrm{~mm}$ mesh sieve, homogenized and finally an aliquot was separated for chemical analyses. Determination of soil $\mathrm{pH}$, total carbon, organic matter and $\mathrm{P}, \mathrm{K}, \mathrm{Ca}, \mathrm{Mg}, \mathrm{S}$, sum of bases and cation exchange capacity (CEC) was according to Raij et al. (2001).

Extraction of $\mathrm{Zn}, \mathrm{Ni}, \mathrm{Cu}, \mathrm{Cd}, \mathrm{Cr}, \mathrm{Pb}, \mathrm{Mn}$ and $\mathrm{Fe}$ was carried out using a $0.05 \mathrm{M}$ solution of diethylenetriaminepentacetic acid (DTPA) and determination by ICP-OES (Model Optma 7300 DV, Perkin Elmer).

Table 1 -Chemical characterization of soil used in the experiment.

\begin{tabular}{|c|c|c|c|c|c|c|c|c|c|c|c|c|c|}
\hline $\mathrm{pH}$ & $\mathrm{P}$ & $\mathrm{K}$ & P-rem & $\mathrm{Ca}^{2+}$ & $\mathrm{Mg}^{2+}$ & $\mathrm{Al}^{3+}$ & $\mathrm{H}+\mathrm{Al}$ & SB & $\mathrm{t}$ & $\mathrm{T}$ & $\mathrm{V}$ & $\mathrm{m}$ & $\mathrm{OM}$ \\
\hline $\mathrm{H}_{2} \mathrm{O}$ & \multicolumn{3}{|c|}{$\mathrm{mg} \mathrm{dm}^{-3}$} & \multicolumn{6}{|c|}{$\mathrm{cmol}_{\mathrm{c}} \mathrm{dm}^{-3}$} & \multicolumn{3}{|c|}{$-\%-$} & $\%$ \\
\hline 5.6 & 0.5 & 41 & 7 & 0.6 & 0.4 & 0.0 & 2.1 & 1.1 & 1.1 & 3.2 & 35 & 0 & 0.8 \\
\hline
\end{tabular}

P-rem=remaining P; $\mathrm{SB}=$ Sum of bases; $\mathrm{t}=$ Effective $\mathrm{CEC}$; $\mathrm{T}=$ Potential $\mathrm{CEC}$; V=Bases saturation; $\mathrm{m}=$ Aluminum saturation; $\mathrm{OM}=$ Organic Matter. 
After incubation, a lettuce (Lactuca sativa) seedling was transferred to each pot and allowed to grow for 45 days. After that period, plants were cut even with the substrate surface for physic and chemical analyses. Sludge sewage application in lettuce crop is prohibited by Brazilian Law (CONAMA, 2006). However, the lettuce was chosen as test plant because it is very sensitive to the presence of metals in the soil and the evaluation of contamination levels of this plant with heavy metals is an important indicator for the risk assessment of the use of organic waste in agriculture (SAMPAIO et al., 2009).

The number of leaves per plant (NLP), diameter (D), weight $(\mathrm{W})$ and dry matter (DM) were analyzed in order to assess plant growth. DM was obtained by forced air drying method in an oven at a temperature of $60^{\circ} \mathrm{C}$.

After weighing, $1 \mathrm{~g}$ samples of leaves were digested in a mixture containing $\mathrm{HNO}_{3}, \mathrm{H}_{2} \mathrm{SO}_{4}$ and $\mathrm{HClO}_{4}(5: 1: 1)$ at $80{ }^{\circ} \mathrm{C}$. After, the digested sample was filtered and was finally maintained to $50 \mathrm{ml}$ with distilled water. Concentration of heavy metals was determined by ICP-OES (Model Optma 7300 DV, Perkin Elmer).

The analysis recovery was measured in order to evaluate its veracity.

Data obtained underwent variance analyses (ANOVA) and means were tested by Skott Knott test at $5 \%$ significance, utilizing the statistical program Sisvar (FERREIRA, 2011).

Heavy metals analyses precision and accuracy were validated by simultaneous analyses of certified samples from Institute for Reference Materials and Measurements from European Commission. Certified sewage sludge samples BCR-144R and BCR-145R, and from soil treated with sewage sludge CRM-143R were analyzed under the same methodological procedures described. The recovery factor of analysis was measured to evaluate its veracity (BRASIL, 2011) (Table 2).

\section{RESULTSAND DISCUSSION}

Sewage sludge presented high quantities of nutrients, organic matters and almost neutral $\mathrm{pH}$, appropriate to be used in agriculture. Besides, contents of heavy metals were below maximum limits allowed by the Brazilian Law (CONAMA, 2006), revealing its potential to be applied to soil (Table 3 ).

The effect of sewage sludge application on soil chemical characteristics is presented in table 4. Organic matter increased significantly with larger doses of applied sludge. In the $180 \mathrm{tha}^{-1}$ treatment, increase was of $435 \%$ when compared to control.

Sewage sludge influenced soil CEC at the two larger concentrations, which were statistically identical and presented an increase of $49 \%$ and $69 \%$. Total carbon contents also increased at the 120 and $180 \mathrm{t} \mathrm{ha}^{-1}$ concentrations, with increases of 337 and $463 \%$, respectively.

Soil $\mathrm{pH}$ was not influenced by treatments and values were around 6.5. According to Nielson et al. (1998), sludge application increases soil $\mathrm{pH}$ duo to of the calcium carbonate in the residue. On the other hand, production of organic acids during the process of biodegradation of the organic fraction of the residue and nitrification may contribute to the acidification of the soil (SOMMERS, 1977). In this study, the application of sludge did not influence soil $\mathrm{pH}$, which on the other hand, was affected by application of lime to all treatments.

The sum of bases was affected by the application of sludge in the 120 and $180 \mathrm{t} \mathrm{ha}^{-1}$ concentrations, increasing, respectively, 55 and $71 \%$, which do not differ statistically. Sludge significantly increased P, K, Ca, Mg and $\mathrm{S}$ cocntents, which, in the treatment with application of $180 \mathrm{t} \mathrm{ha}^{-1}$, had gains of 797, 202, 63 and 4,773\%, respectively, when compared to control.

Table 2 - Comparison of results of metal concentration on certified materials.

\begin{tabular}{cccccccccc}
\hline $\begin{array}{c}\text { Metals } \\
\left(\mathrm{mg} \mathrm{dm}^{-3}\right)\end{array}$ & \multicolumn{3}{c}{ BCR 144-R } & \multicolumn{3}{c}{ BCR 145-R } & \multicolumn{3}{c}{ CRM 143-R } \\
\hline & Certified & Found & $\mathrm{f}_{\text {rec } \%} \%$ & Certified & Found & $\mathrm{f}_{\text {rec }} \%$ & Certified & Found & $\mathrm{f}_{\text {rec }} \%$ \\
$\mathrm{Cd}$ & $1.84 \pm 0.07$ & 1.8 & 97.8 & $3.50 \pm 0.15$ & 3.5 & 100 & $72 \pm 1.8$ & 70.1 & 97.4 \\
$\mathrm{Cr}$ & $90 \pm 6$ & 94 & 104.4 & $307 \pm 13$ & 294 & 95.8 & $426 \pm 12$ & 418 & 98.1 \\
$\mathrm{~Pb}$ & $96 \pm 1.6$ & 98 & 102.1 & $282 \pm 9$ & 285 & 101.1 & $174 \pm 5$ & 180 & 103.4 \\
$\mathrm{Mn}$ & $189 \pm 6$ & 193 & 102.1 & $156 \pm 4$ & 153 & 98.1 & $858 \pm 11$ & 859 & 100.1 \\
$\mathrm{Ni}$ & $44.9 \pm 1.5$ & 43 & 95.8 & $251 \pm 6$ & 255 & 101.6 & $1063 \pm 16$ & 1051 & 98.9 \\
\hline
\end{tabular}

$\mathrm{f}_{\mathrm{rec}}=$ Recovery fator.

Ciênc. agrotec., Lavras, v. 37, n. 6, p. 512-520, nov./dez., 2013 
Table 3 - Physical and chemical attributes of sewage sludge.

\begin{tabular}{lc}
\hline \multicolumn{1}{c}{ Parameters } & Concentration \\
\hline Total Solids $(\%)$ & $32.4 \pm 0.2$ \\
Soluble Solids $(\%)$ & $22.9 \pm 0.6$ \\
Inorganic Solids $(\%)$ & $9.5 \pm 0.5$ \\
Humidity $(\%)$ & $67.6 \pm 0.9$ \\
$\mathrm{pH}$ & $6.4 \pm 0.1$ \\
$\mathrm{Total} \mathrm{C}\left(\mathrm{g} \mathrm{dm}^{-3}\right)$ & $152.7 \pm 17.4$ \\
$\mathrm{~N}(\%)$ & $3.4 \pm 0.06$ \\
$\mathrm{Organic} \mathrm{Matter}\left(\mathrm{g} \mathrm{dm}^{-3}\right)$ & $262.3 \pm 29.7$ \\
$\mathrm{P}\left(\mathrm{mg} \mathrm{dm}^{-3}\right)$ & $347.5 \pm 18.8$ \\
$\mathrm{~K}\left(\mathrm{mmol}_{\mathrm{c}} \mathrm{dm}^{-3}\right)$ & $19.5 \pm 4.1$ \\
$\mathrm{Ca}\left(\mathrm{mmol}_{\mathrm{c}} \mathrm{dm}^{-3}\right)$ & $216.5 \pm 30.4$ \\
$\mathrm{Mg}\left(\mathrm{mmol}_{\mathrm{c}} \mathrm{dm}^{-3}\right)$ & $45 \pm 6$ \\
$\mathrm{Fe}\left(\mathrm{mg} \mathrm{Kg}^{-1}\right)$ & $372.3 \pm 33.4$ \\
$\mathrm{~S}\left(\mathrm{mg} \mathrm{Kg}^{-1}\right)$ & $713 \pm 24.1$ \\
$\mathrm{Cd}\left(\mathrm{mg} \mathrm{Kg}^{-1}\right)$ & $0.2 \pm 0.06$ \\
$\mathrm{~Pb}\left(\mathrm{mg} \mathrm{Kg}^{-1}\right)$ & $0.3 \pm 0.06$ \\
$\mathrm{Ni}\left(\mathrm{mg} \mathrm{Kg}^{-1}\right)$ & $118 \pm 5.5$ \\
$\mathrm{Cr}\left(\mathrm{mg} \mathrm{Kg}^{-1}\right)$ & $0.3 \pm 0.07$ \\
$\mathrm{Cu}\left(\mathrm{mg} \mathrm{Kg}^{-1}\right)$ & $8.3 \pm 2.7$ \\
$\mathrm{Mn}\left(\mathrm{mg} \mathrm{Kg}^{-1}\right)$ & $11.2 \pm 3.3$ \\
$\mathrm{Zn}\left(\mathrm{mg} \mathrm{Kg}^{-1}\right)$ & $184.9 \pm 46.6$ \\
\hline
\end{tabular}

The increase of sludge concentration improved soil fertility in a relevant way, by increasing contents of organic matter, total carbon, CEC and nutrients. This improvement occurred due to high levels of nutrients and organic matter of the residue. Several authors also obtained relevant improvements in the nutritional status of soil with the application of sewage sludge (SINGH; AGRAWAL, 2010; ANGIN et al., 2012).

Soil contents of metals in each treatment and the maximum limits established by the Brazilian Law (CONAMA, 2006) are presented in table 5. Metal contents were lower than those allowed by legislation, even in the treatment with a higher concentration of applied sludge.

The metals $\mathrm{Zn}$ and Ni presented the highest contents, which vary, respectively, from 0.4 to 69.7 and from 0.3 to $9.3 \mathrm{mg} \mathrm{dm}^{-3}$. Such results confirm expectations, since they were the metals with the highest concentration in the sludge (Table 3). In the control treatment, Cd was below the detection level of the analytical technique. In the other treatments, there was no significant variation. In relation to $\mathrm{Pb}, \mathrm{Cu}, \mathrm{Fe}$ and $\mathrm{Mn}$, the largest levels were obtained with the application of $180 \mathrm{tha}^{-1}$.

Correspondence between sewage sludge doses and heavy metals contents on leaves are present in figure 1. $\mathrm{Zn}$ increased from 55.6 to $218.4 \mathrm{mg} \mathrm{dm}^{-3}$ comparing control to 60 tha $^{-1}$ treatment. Already, 120 and 180 tha $^{-1}$ treatments presented relevant reduction to 96.3 and $89.4 \mathrm{mg} \mathrm{dm}^{-3}$, respectively. $\mathrm{Cu}$ contents presented the same behavior, with increases of 4.54 to $117.2 \mathrm{mg} \mathrm{dm}^{-3}$ from control to $60 \mathrm{t}$ $\mathrm{ha}^{-1}$ and reduction of 8.1 and $7.7 \mathrm{mg} \mathrm{dm}^{-3}$ in 120 and $180 \mathrm{t}$ $\mathrm{ha}^{-1}$ treatments. As for Mn, the $120 \mathrm{tha}^{-1}$ treatment was the only one that differed statistically from the others, with a content of $90.5 \mathrm{mg} \mathrm{dm}^{-3}$, which was the lowest mean. The highest $\mathrm{Cd}$ and $\mathrm{Cr}$ values were obtained with $60 \mathrm{t} \mathrm{ha}^{-1}$. The other results did not differ from the statistical stand point.

Table 4 - Soil chemical properties after application of different concentrations of sewage sludge.

\begin{tabular}{lrrrrrr}
\hline Parameters & $0 \mathrm{t} \mathrm{ha}^{-1}$ & $60 \mathrm{t} \mathrm{ha}^{-1}$ & $120 \mathrm{tha}^{-1}$ & $180 \mathrm{t} \mathrm{ha}^{-1}$ & \multicolumn{1}{c}{ Test F } & \multicolumn{1}{c}{$\mathrm{CV} \%$} \\
\hline $\mathrm{OM}\left(\mathrm{g} \mathrm{dm}^{-3}\right)$ & $8.5 \mathrm{a}$ & $17.2 \mathrm{~b}$ & $41.2 \mathrm{c}$ & $45.5 \mathrm{~d}$ & $<0.0001$ & 7.51 \\
$\mathrm{CEC}\left(\mathrm{mg} \mathrm{dm}^{-3}\right)$ & $296.7 \mathrm{a}$ & $330.7 \mathrm{a}$ & $442.9 \mathrm{~b}$ & $503.8 \mathrm{~b}$ & 0.0032 & 17.22 \\
Total Carbon & $4.75 \mathrm{a}$ & $10 \mathrm{a}$ & $20.8 \mathrm{~b}$ & $26.8 \mathrm{c}$ & $<0.0001$ & 18.59 \\
$\mathrm{pH}$ & $6.5 \mathrm{a}$ & $6.6 \mathrm{a}$ & $6.5 \mathrm{a}$ & $6.4 \mathrm{a}$ & 0.1308 & 1.48 \\
$\mathrm{SB}\left(\mathrm{mmol}_{\mathrm{c}} \mathrm{dm}^{-3}\right)$ & $289.2 \mathrm{a}$ & $318.7 \mathrm{a}$ & $448.1 \mathrm{~b}$ & $494.4 \mathrm{~b}$ & 0.0013 & 16.05 \\
$\mathrm{P}\left(\mathrm{mg} \mathrm{dm}^{-3}\right)$ & $8.75 \mathrm{a}$ & $29.7 \mathrm{~b}$ & $47 \mathrm{c}$ & $78.5 \mathrm{~d}$ & $<0.0001$ & 9.59 \\
$\mathrm{~K}\left(\mathrm{mmol}_{\mathrm{c}} \mathrm{dm}^{-3}\right)$ & $1.45 \mathrm{a}$ & $1.72 \mathrm{a}$ & $3 \mathrm{~b}$ & $4.4 \mathrm{~b}$ & $<0.0001$ & 13.76 \\
$\mathrm{Ca}\left(\mathrm{mmol}_{\mathrm{c}} \mathrm{dm}^{-3}\right)$ & $277 \mathrm{a}$ & $306.8 \mathrm{a}$ & $417.5 \mathrm{~b}$ & $488.2 \mathrm{~b}$ & 0.0058 & 19.99 \\
$\mathrm{Mg}\left(\mathrm{mmol}_{\mathrm{c}} \mathrm{dm}^{-3}\right)$ & $10.8 \mathrm{a}$ & $9.8 \mathrm{a}$ & $13.5 \mathrm{a}$ & $17.5 \mathrm{~b}$ & 0.0076 & 21.21 \\
$\mathrm{~S}\left(\mathrm{mg} \mathrm{dm}^{-3}\right)$ & $20.5 \mathrm{a}$ & $502.5 \mathrm{~b}$ & $757.8 \mathrm{c}$ & $999 \mathrm{~d}$ & $<0.0001$ & 14.66 \\
\hline
\end{tabular}

* Means followed by the same letter in the lines do not differ according to Skott Knott test at $\mathrm{p}<0.05$. CV\% $=$ Coefficient of Variation. $\mathrm{OM}=$ Organic matter. $\mathrm{SB}=$ sum of bases. 
Table 5 - Soil heavy metal contents $\left(\mathrm{mg} \mathrm{dm}^{-3}\right)$ with application of various concentrations of sewage sludge.

\begin{tabular}{lcccccccc}
\hline $\begin{array}{c}\text { Treatments } \\
\mathrm{t} \mathrm{ha}^{-1}\end{array}$ & $\mathrm{Cd}$ & $\mathrm{Pb}$ & $\mathrm{Ni}$ & $\mathrm{Cr}$ & $\mathrm{Cu}$ & $\mathrm{Fe}$ & $\mathrm{Mn}$ & $\mathrm{Zn}$ \\
\hline 0 & $<\mathrm{dl}$ & $0.5 \mathrm{c}$ & $0.3 \mathrm{c}$ & 0.3 & $0.2 \mathrm{~d}$ & $2.2 \mathrm{~d}$ & $1.2 \mathrm{~d}$ & $0.40 \mathrm{~d}$ \\
60 & $0.01 \mathrm{a}$ & $0.7 \mathrm{c}$ & $1.1 \mathrm{c}$ & $<\mathrm{dl}$ & $2.2 \mathrm{c}$ & $15.0 \mathrm{c}$ & $2.5 \mathrm{c}$ & $17.0 \mathrm{c}$ \\
120 & $0.02 \mathrm{a}$ & $0.8 \mathrm{~b}$ & $6.2 \mathrm{~b}$ & $<\mathrm{dl}$ & $5.6 \mathrm{~b}$ & $47.2 \mathrm{~b}$ & $3.7 \mathrm{~b}$ & $43.0 \mathrm{~b}$ \\
180 & $0.02 \mathrm{a}$ & $1.1 \mathrm{a}$ & $9.4 \mathrm{a}$ & $<\mathrm{dl}$ & $8.6 \mathrm{a}$ & $82.5 \mathrm{a}$ & $5.6 \mathrm{a}$ & $69.7 \mathrm{a}$ \\
CONAMA & 2 & 20.5 & 37 & 77 & 158.5 & --- & --- & 222.5 \\
Test F & 0.0010 & 0.0008 & $<0.0001$ & --- & $<0.0001$ & $<0.0001$ & $<0.0001$ & $<0.0001$ \\
CV\% & 18.20 & 19.51 & 15.84 & -- & 18.98 & 20.8 & 21.50 & 17.30 \\
\hline
\end{tabular}

Means followed by the same letter in the columns do not differ according to Skott Knott test at $\mathrm{p}<0.05$. $\mathrm{dl}=$ detection level. CV\% $=$ Coefficient of Variation.

As far as $\mathrm{Ni}$ is concerned, there was a significant increase from 1.4 to $16.5 \mathrm{mg} \mathrm{dm}^{-3}$ comparing control to $60 \mathrm{t} \mathrm{ha}^{-1}$ concentration. Treatments with 120 and $180 \mathrm{t}$ $\mathrm{ha}^{-1}$ concentrations presented reduction to 3.4 and 4.2 $\mathrm{mg} \mathrm{dm}^{-3}$, respectively. There was no difference from the statistical stand point among treatments concerning Fe contents on lettuce leaves. In this case, values varied from 951 to $2,360 \mathrm{mg} \mathrm{dm}^{-3}$. For $\mathrm{Pb}$ the highest means were observed in treatments with $120 \mathrm{t} \mathrm{ha}^{-1}\left(14.1 \mathrm{mg} \mathrm{dm}^{-3}\right)$ and $180 \mathrm{t} \mathrm{ha}^{-1}\left(17 \mathrm{mg} \mathrm{dm}^{-3}\right)$, statistically identical.

Metals must be bioavailable to be absorbed. Metal bioavailability is influenced by soil properties, i.e., $\mathrm{pH}$, organic matter, iron oxides, as well as sludge application rate (HUE; RANJITH, 1994). Though metal contents in the soil have increased after application of sewage sludge, $\mathrm{Cd}, \mathrm{Cr}, \mathrm{Zn}, \mathrm{Ni}$ and $\mathrm{Cu}$ were less absorbed by plants in $120 \mathrm{tha}^{-1}$ and $180 \mathrm{tha}^{-1}$ treatments. These results were different from those obtained by Singh and Agrawal (2010), who identified an increase in metal contents in bean plants by increasing sewage sludge doses. However, distinctly, those authors used much lower doses, the maximum being $12 \mathrm{t} \mathrm{ha}^{-1}$.

According to Tsutiya (2002), a reduction of metal contents in the plant, despite the increase of organic compound doses, maybe related to increment of soil organic matter, which acts as immobilizator and regulator of heavy metals availability to plants. Therefore, the application of sewage sludge at $120 \mathrm{t}$ $\mathrm{ha}^{-1}$ and $180 \mathrm{tha}^{-1}$ supplied large quantities of organic matter to soil diminishing availability and reducing absorption of those metals. In the $60 \mathrm{t} \mathrm{ha}^{-1}$ treatment, organic matter added to the soil was not enough to reduce metals availability.
Sludge application did not influence Fe contents in plant leaf tissue and affected Mn absorption only in the $120 \mathrm{t} \mathrm{ha}^{-1}$ treatment. This probably occurred due to previous soil high levels of those metals. Those elements are essential nutrients to plants and other organisms and, according to Marques, Melo and Marques (2002), present low risk, their disposal in larger quantities in agriculture soils being accepted. This practice is in accordance with law, which does not established maximum limits for those metals in sewage sludge for use in agriculture.

$\mathrm{Pb}$ absorption increased by increasing applied doses, its availability suffering no reduction due to increase of organic matter in the soil. According to Baird and Cann (2011), lettuce absorbs large quantities of that metal, accumulating the element on the leaf tissue. In relation to plants growth, sludge application significantly affected plants W, DM, NLP and D (Table 6).

The lowest plant weight mean was in the control treatment, followed by treatment with $60 \mathrm{t} \mathrm{ha}^{-1}$, while $120 \mathrm{t} \mathrm{ha}^{-1}$ and $180 \mathrm{tha}^{-1}$ treatments were statistically equal, presenting the highest values. In relation to the other variables, NLP, DM and D, gradual increase was observed up to the $120 \mathrm{tha}^{-1}$ concentration and reduction at the $180 \mathrm{t} \mathrm{ha}^{-1}$ concentration.

Lavado (2006) reported that improvement in soil properties due to sewage sludge application increases plant productivity. In every variable considered to evaluate plants growth, control treatment presented the lowest means. These low values may be explained by the low nutrients concentration in the soil, negatively influencing plant growth and may result in slight reduction to total loss of the vegetal production (SILVA; YANAKA; TOSCANO, 2011). 

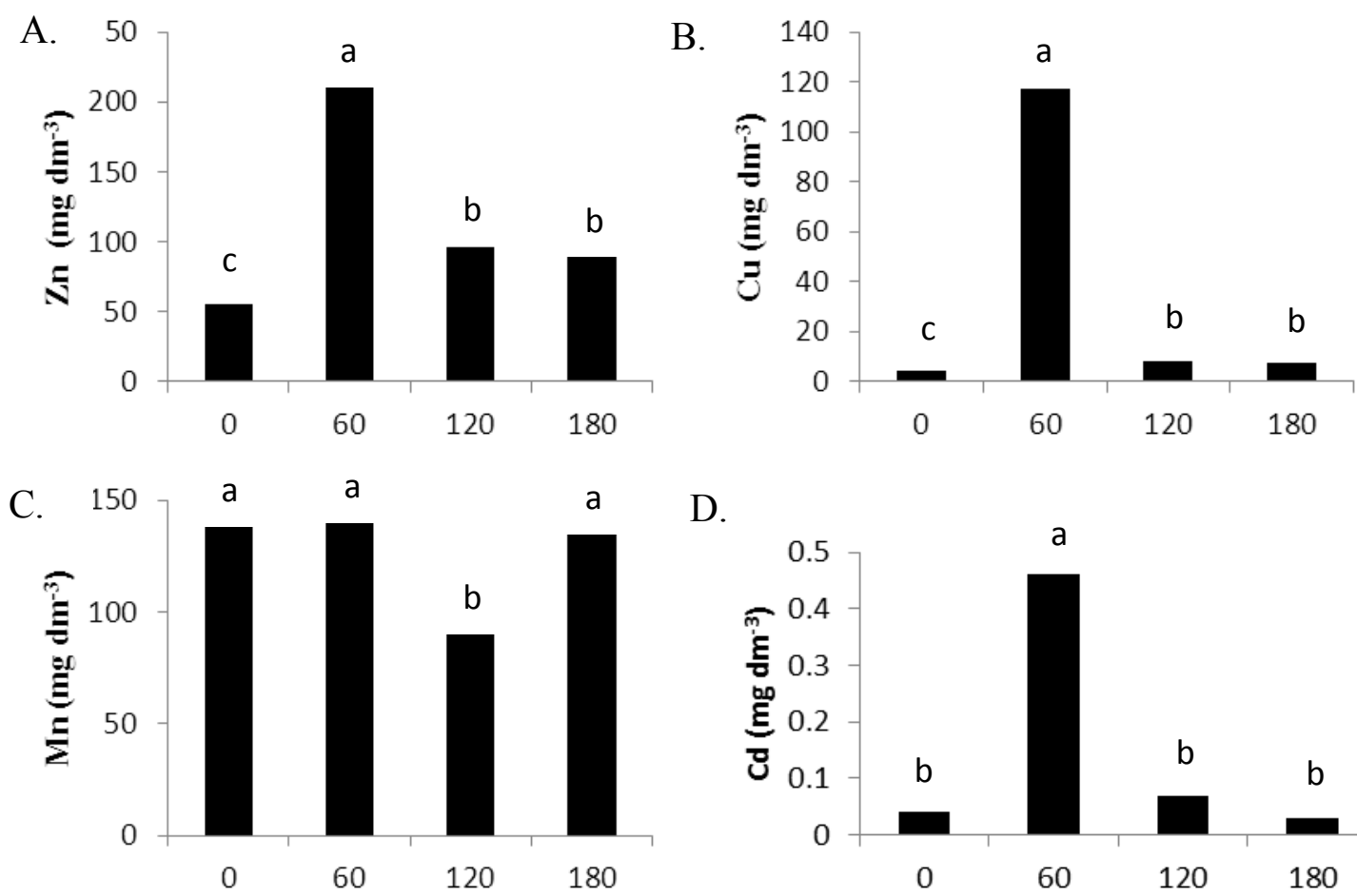

D.
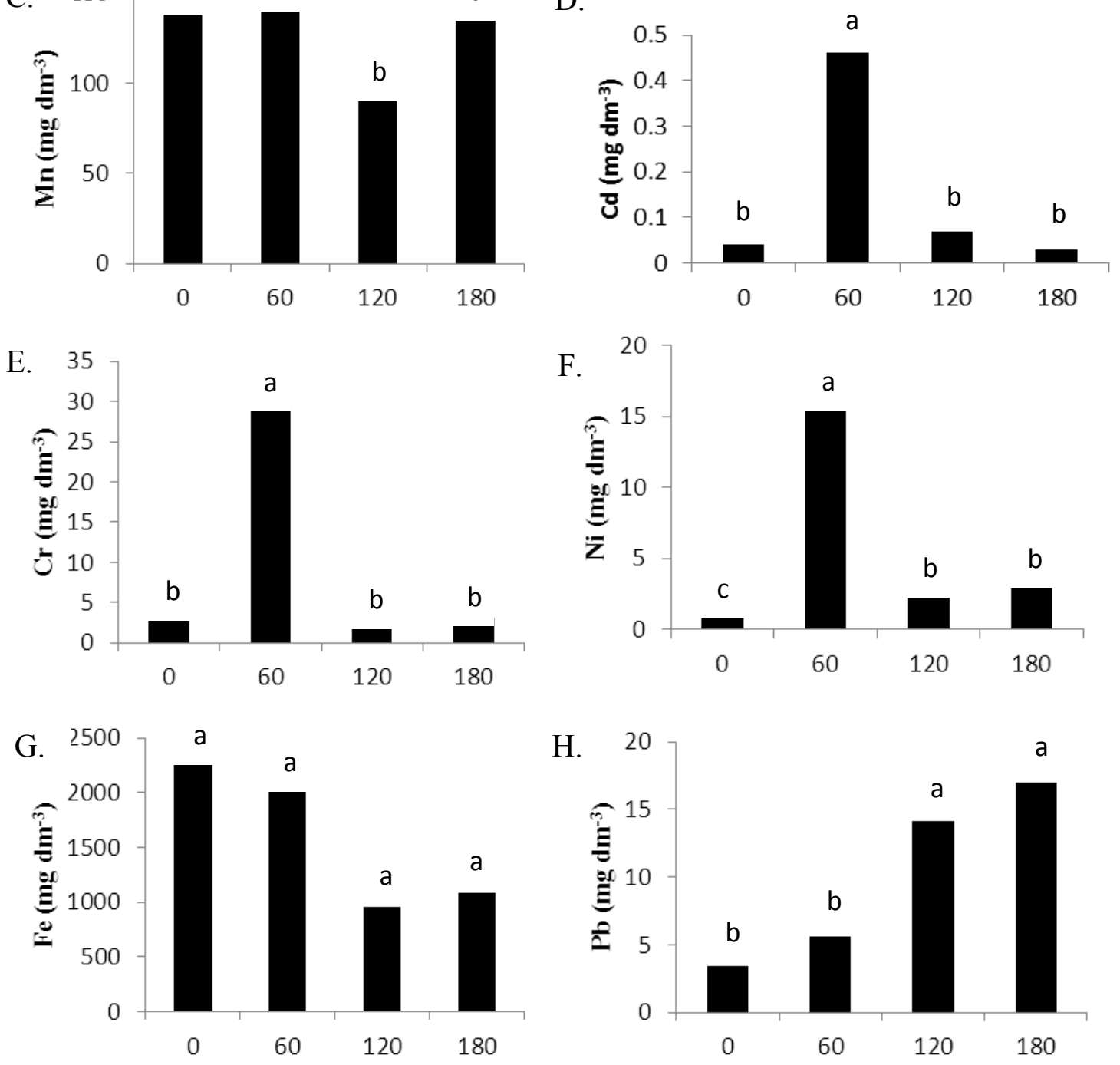

H.

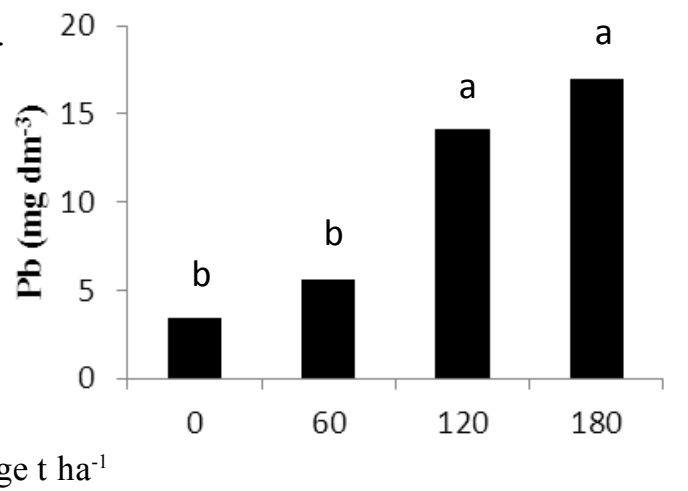

Figure 1 - $\mathrm{Zn}(\mathrm{A}), \mathrm{Cu}(\mathrm{B}), \mathrm{Mn}(\mathrm{C}), \mathrm{Cd}(\mathrm{D}), \mathrm{Cr}(\mathrm{E}), \mathrm{Ni}(\mathrm{F}), \mathrm{Fe}(\mathrm{G})$ and $\mathrm{Pb}(\mathrm{H})$ accumulation on leaves. Bars followed by the same letters do not differ statistically according to Skott Knott test at $\mathrm{p}<0.05$. 
Table 6 - Comparison of means obtained for weight, dry biomass, number of leaves per plant and plant diameter found at different treatment.

\begin{tabular}{ccccc}
\hline Treatments $\left(\mathrm{t} \mathrm{ha}^{-1}\right)$ & $\mathrm{W}(\mathrm{g})$ & DM $(\mathrm{g})$ & NLP & D $(\mathrm{cm})$ \\
\hline 0 & $9.95 \mathrm{c}$ & $0.58 \mathrm{~d}$ & $8.00 \mathrm{c}$ & $8.98 \mathrm{~d}$ \\
60 & $27.17 \mathrm{~b}$ & $2.12 \mathrm{c}$ & $17.75 \mathrm{~b}$ & $18.32 \mathrm{c}$ \\
120 & $80.15 \mathrm{a}$ & $7.58 \mathrm{a}$ & $27.50 \mathrm{a}$ & $31.40 \mathrm{a}$ \\
180 & $73.87 \mathrm{a}$ & $4.77 \mathrm{~b}$ & $19.25 \mathrm{~b}$ & $28.12 \mathrm{~b}$ \\
Test F & $<0.0001$ & $<0.0001$ & $<0.0001$ & $<0.0001$ \\
CV\% & 9.51 & 15.50 & 18.16 & 8.70 \\
\hline
\end{tabular}

* Means followed by the same letter do not differ according to Scott-Knott test at $\mathrm{p}<0.05$. CV\% $=$ Coefficient of Variation. W $=$ weight. $\mathrm{DM}=$ dry mater. $\mathrm{NLP}=$ number of leaves per plant. $\mathrm{D}=$ diameter.

Sludge application led to an increase in plant production, due to a larger concentration of nutrients supplied to the soil, specially $\mathrm{N}$ and P. According to Cecato et al. (2000), P acts on respiration and energy production, intensifying cell division and root system development. On the other hand, $\mathrm{N}$ is the main protein constituent which actively takes part in the synthesis of organic compounds of the vegetal structure and, therefore, is responsible for the characteristics linked to plants growth.

Another factor that may have favored the enhancement in plant production was the improvement of soil physical conditions. Application of sludge may lead to a soil density reduction and an increase of porosity, improving retention and infiltration of water and favoring roots growth, contributing to a better plant development (AGGELIDES; LONDRA, 2000).

In the $180 \mathrm{tha}^{-1}$ treatment there was reduction in the number of leaves per plant, in dry matter and in plant diameter. The reduction was not related to toxicity caused by heavy metals, since metal absorption by the plants was reduced in this treatment.

In accordance with Domene et al. (2008), residues toxicity may not be related to the polluting charge, at least in short term, but mainly by harmful compounds, such as ammonium, that is released during residue decomposition in the soil. Therefore, it is possible that the reduction in plant production in the $180 \mathrm{t} \mathrm{ha}^{-1}$ treatment is due to excess ammonium released in the soil in consequence of the high concentration of applied sludge.

Other authors also observed reduction in plant production after application of high doses of sewage sludge and increased production with intermediate doses (SINGH; SINHA, 2004; SINGH; AGRAWAL, 2010).

\section{CONCLUSIONS}

Application of sewage sludge increased carbon, organic matter, $\mathrm{CEC}$ and nutrients contents, increasing soil fertility. Heavy metals contents also increased, though at levels lower than limits established by the Brazilian Law. Plants presented positive growth due to larger availability of nutrients up to the treatment of $120 \mathrm{tha}^{-1}$. However, with the $180 \mathrm{t} \mathrm{ha}^{-1}$ treatment there was reduction of dry matter, number of leaves per plant and plant diameter, therefore, negatively influencing plant growth.

A reduction in the absorption of $\mathrm{Cd}, \mathrm{Cr}, \mathrm{Zn}, \mathrm{Ni}$ and $\mathrm{Cu}$ was observed with treatments with the highest concentrations of applied sewage sludge, which confirmed the hypothesis that the organic matter supplied to the soil by sewage sludge decreases the availability of heavy metals. Results show that the sewage sludge used presents high potential to be applied as fertilizer in agriculture and as soil conditioner, but its application in soils should be made in a controlled manner, respecting the legislation, so that the benefits outweigh the risks of environmental pollution.

\section{ACKNOWLEDEMENTS}

The authors thank the UNIFENAS for allowing the use of the greenhouse where the experiment was carried out, the COPASA for the sewage sludge samples and the COOXUPÉ for carrying out the chemical analyses.

\section{REFERENCES}

AGGELIDES, S.M.; LONDRA, P.A. Effects of compost produced from town wastes and sewage sludge on the physical properties of a loamy and clay soil.

Bioresource Technology, Amsterdam, v.71, n.3, p.253$259,2000$. 
ALLISON, F.A. Soil Organic Matter and Its Role in Crop Production. Amsterdam: Elsevier, 1973. 631p.

ANGIN, I. et al. Changes in chemical properties of soil and sour cherry as a result of sewage sludge application. Horticultural Science, Prague, v.39, n.2, 61-66, 2012.

BAIRD, C.; CANN, M. Química Ambiental. Porto Alegre: Bookman, 4.ed., 2011.844p.

BRASIL. Ministério da Agricultura, Pecuária e Abastecimento. Guia de validação e controle de qualidade analítica: fármacos em produtos para alimentação e medicamentos veterinários / Ministério da Agricultura, Pecuária e Abastecimento. Secretaria de Defesa Agropecuária. - Brasília: MAPA, 2011.72p.

CECATO, U.; YANAKA, F.Y.; TOSCANO, M.R.B.F; Influência da adubação nitrogenada e fosfatada na produção, na rebrota e no perfilhamento do capimmarandu (Brachiaria brizantha Hochst. Stapf. cv. Marandu). Acta Scientiarum, Maringa, v.22, n.3, p.817-822, 2000.

CESAR, R. et al. Influence of the properties of tropical soils in the toxicity and bioavailability of heavy metals in sewage sludge-amended lands.

Environmental Earth Science, Berlin, v.66, n.8, p.2281$2292,2012$.

CONSELHO NACIONAL DO MEIO AMBIENTE CONAMA. Resoluções no 375 e n' 380 , de 29 de agosto de 2006. http://www.mma.gov.br/port/conama/ res06/res37506.pdf $>$. Acesso em: 01 de Julho de 2010.

DOMENE, X. et al. Ecological risk assessment of organic waste amendments using the species sensitivity distribution from a soil organisms test battery. Environmental Pollution, Amsterdam, v.155, n.2, p.227-236, 2008.

FERREIRA, D.F. Sisvar: a computer statistical analysis system. Ciência e Agrotecnologia, Lavras, v.35, n.6, p. 1039-1042, nov./dec. 2011.

HUE, N.V.; RANJITH, S.A. Sewage sludges in Hawaii: chemical composition and reactions with soils and plants. Water Air Soil Pollution, Berlin, v.72, n.1-4, p.265-283, 1994.
KORF, P.E. et al. Retenção de metais em solo da antiga área de disposição de resíduos sólidos urbanos de Passo Fundo - RS. Revista de Ciências Ambientais, Canoas, v.2, n.2, p.43-60, 2008.

LAVADO, R.S. Effects of sewage sludge application on soils and sunflower yield: quality and toxic element accumulation. Journal of Plant Nutrition, New York, v.29, n.6, p.975-984. 2006.

LIAO, Y.C. et al. Effect of transpiration on Pb uptake by lettuce and on water soluble low molecular weight organic acids in rhizosphere. Chemosphere, Amsterdam, v.65, n.2, p.343-351, 2006.

MARQUES, M.O; MELO, W.J. de; MARQUES, T.A. Metais pesados e o uso de biossólidos na agricultura. In: TSUTIYA, M.T. et al. Biossólidos na Agricultura. 2.ed., São Paulo: ABES/SP, p.365-403, 2002.

NIELSON, G.H. et al. Evaluation of organic wastes as soil amendments for cultivation of carrot and chard on irrigated sandy soils. Canadian Journal of Soil Science, Ottawa, v.78, n.1, p.217-225, 1998.

RAIJ, B. VAN. et al. Análises químicas para avaliação da fertilidade de solos tropicais. Campinas: Instituto Agronômico de Campinas, 2001. 285p.

SAMPAIO, R.A. et al. Caracterização qualitativa e quantitativa de metais pesados em alface adubada com composto de lixo urbano. Revista Brasileira de Engenharia Agrícola e Ambiental, Campina Grande, v.13, n.5, p.948-954, 2009.

SHUMAN, L.M. Organic waste amendments effect on zinc fractions of two soils. Journal of

Environmental Quality, Madison, v.28, n.5, p.14421447, 1999.

SILVA, A.A.; COSTA, A.M.; LANA, R.M. Q. Absorção de micronutrientes em pastagem de brachiaria decumbens, após aplicação de cama de peru e fontes minerais na fertilização. Bioscience Journal, Uberlândia, v.27, n.1, p.41-48, 2011.

SINGH, R.P., AGRAWAL, M.M. Potential benefits and risks of land application of sewage sludge. Waste Management, Amsterdam, v.28, n.2, p.347-358, 2008. 
SINGH, R.P., AGRAWAL, M.M. Effect of different sewage sludge applications on growth and yield of Vigna radiata L. field crop: Metal uptake by plant. Ecological

Engineering, Amsterdam, v.36, n.7, p.969-972, 2010.

SINGH, S.; SINHA, S. Scanning electron microscopic studies and growth response of the plant of Helianthus annus L. grown on tannery sludge amended soil. Environmental International, Amsterdam, v.30, n.3, p.389-395, 2004.
SOMMERS, L.E. Chemical composition of sewage sludges and analysis of their potential use as fertilizers. Journal of Environmental Quality, Madison, v.6, n.2, p.225-232, 1977.

TSUTIYA, M.T. Características de biossólidos gerados em Estações de Tratamento de Esgotos. In: TSUTIYA, M.T. et al. Biossólidos na Agricultura. 2.ed. São Paulo: ABES/SP, 2002. p.89-131. 